\title{
Current Practice of Global Bariatric Tourism—Survey-Based Study
}

\author{
Piotr K. Kowalewski ${ }^{1}$ (D) - Tomasz G. Rogula ${ }^{2}$ - Ariel Ortiz Lagardere ${ }^{3} \cdot$ Haris A. Khwaja $^{4}$ - Maciej S. Walędziak ${ }^{1}$ • \\ Michał R. Janik ${ }^{1}$
}

Published online: 21 June 2019

(C) The Author(s) 2019

\begin{abstract}
Purpose Our goal was to present the experience of bariatric surgeons with medical tourism on a global scale.

Materials and Methods An online-based survey was sent to bariatric surgeons worldwide regarding surgeon's country of practice, number and types of bariatric procedures performed, number of tourists treated, their countries of origin, reasons for travel, follow-up, and complications.

Results Ninety-three responders performed 18,001 procedures in 2017. Sixty-four of those 93 responders operated on foreign patients performing a total of 3740 operations for them. The majority of the responders practice in India $(n=11,17 \%)$, Mexico $(n=10,16 \%)$, and Turkey $(n=6,9 \%)$. Mexico dominated the number of bariatric surgeries for tourists with 2557 procedures performed in 2017. The most frequent procedures provided were laparoscopic sleeve gastrectomy (LSG) provided by $89.1 \%$ of the respondents, laparoscopic Roux-en-Y gastric bypass (40.6\% of respondents), and one anastomosis gastric bypass (37.5\% of respondents).

Conclusion At least $2 \%$ of worldwide bariatric procedures are provided for medical tourists. Countries such as Mexico, Lebanon, and Romania dominate as providers for patients mainly from the USA, UK, and Germany. The lack of affordable bariatric healthcare and long waiting lists are some of the reasons for patients choosing bariatric tourism.
\end{abstract}

Keywords Medical tourism · Obesity $\cdot$ Bariatric surgery $\cdot$ Global surgery $\cdot$ Surgical weight loss

\section{Introduction}

Bariatric and metabolic surgery currently remains the most effective intervention for morbid obesity and continues to gain in popularity in line with the increasing prevalence of obesity as reported by the World Health Organization (WHO) [1]. However, there is a massive burden of obesity and morbid obesity which outstrips the numbers of surgical/endoscopic interventions being done annually. The problem of effective interventions is further limited by public health care providers

Piotr K. Kowalewski

pietia.kowalewski@gmail.com

1 Department of General Surgery, Military Institute of Medicine, Szaserów 128, 04-141 Warszawa, Poland

2 Bariatric and Metabolic Institute, Cleveland Clinic, Cleveland, $\mathrm{OH}$, USA

3 Obesity Control Center, Tijuana, Mexico

4 Phoenix Health Bariatric Surgery Supercentre University Hospital Aintree, Liverpool, UK hence resulting in some patients relying on services in the private sector in their country of origin which can be expensive. Consequently, some patients are turning to one of the byproducts of globalization - medical tourism - to manage their obesity [2]. Although we know that management strategies for obesity provide millions of dollars in revenue, we are still left with very limited data on the scale and rationale behind the issue.

Our goal was to present the experience of bariatric surgeons with medical tourism on a global scale, relying on the International Bariatric Club (IBC).

\section{Materials and Methods}

An online-based survey was sent to the members of IBC via its mailing list and through social media (Facebook and Twitter). The questions in the 2017 survey focused on surgeon's country of practice, number and types of bariatric procedures performed, number of tourists treated, costs of treatment, tourists' countries of origin, follow-up provided for them, possible complications, and reasons for travel. The 


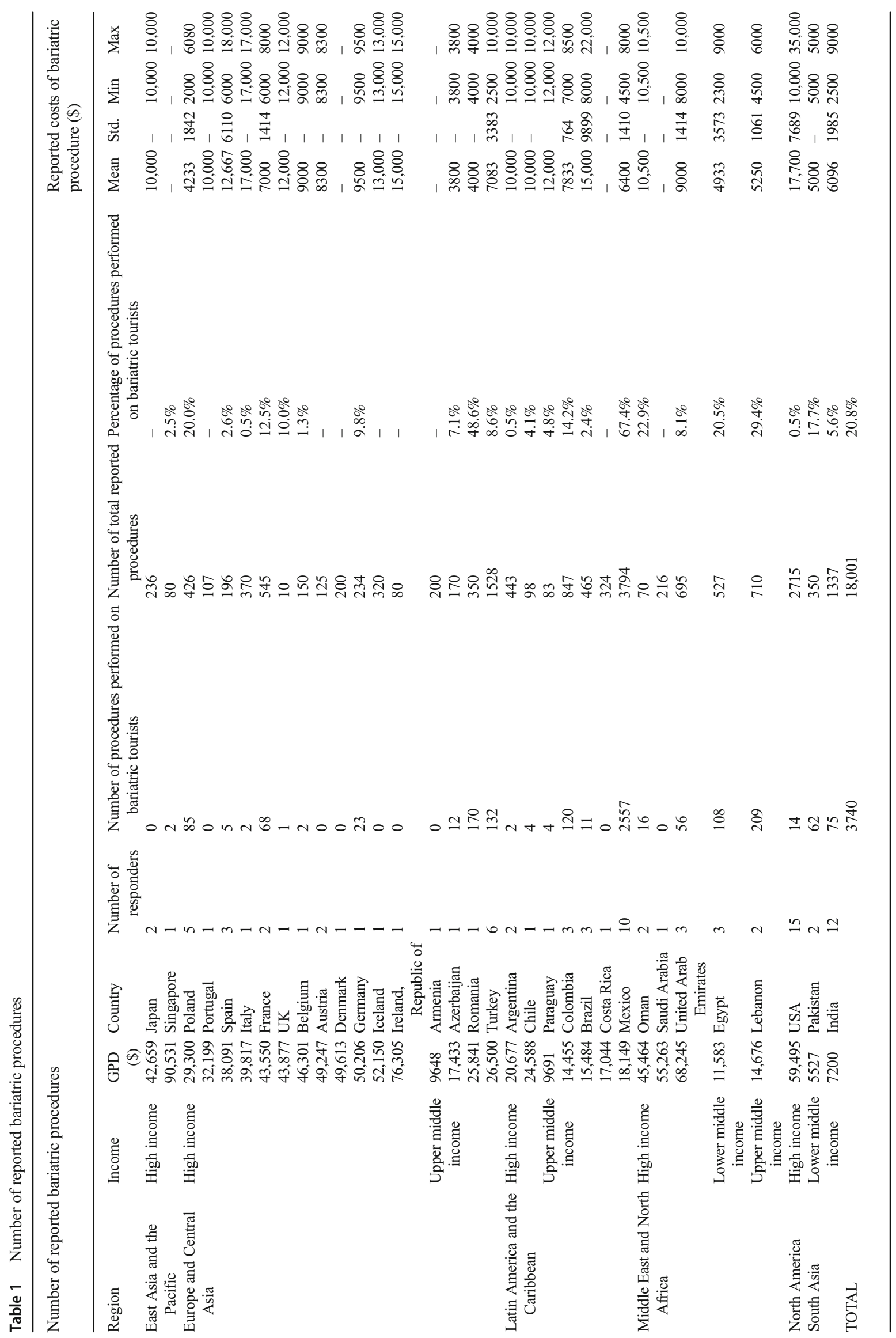


Table 2 Bariatric tourists migration directions

\begin{tabular}{|c|c|}
\hline Direction & Origin Country \\
\hline UK & Pakistan \\
\hline Belgium & $\begin{array}{l}\text { Ivory Coast (Cote d'Ivoire) } \\
\text { Congo }\end{array}$ \\
\hline Italy & $\begin{array}{l}\text { Austria } \\
\text { Croatia }\end{array}$ \\
\hline Singapore & Indonesia \\
\hline Spain & $\begin{array}{l}\text { Colombia } \\
\text { Dominican Republic } \\
\text { Italy }\end{array}$ \\
\hline Chile & $\begin{array}{l}\text { Bolivia } \\
\text { USA }\end{array}$ \\
\hline Paraguay & $\begin{array}{l}\text { Argentina } \\
\text { USA } \\
\text { Brazil }\end{array}$ \\
\hline Azerbaijan & $\begin{array}{l}\text { Russian Federation } \\
\text { UK } \\
\text { Sweden }\end{array}$ \\
\hline Oman & $\begin{array}{l}\text { Afghanistan } \\
\text { Australia } \\
\text { Egypt }\end{array}$ \\
\hline Germany & $\begin{array}{l}\text { Egypt } \\
\text { United Arab Emirates }\end{array}$ \\
\hline United Arab Emirates & $\begin{array}{l}\text { Nigeria } \\
\text { Bahrain } \\
\text { Iraq }\end{array}$ \\
\hline Romania & $\begin{array}{l}\text { United Kingdom } \\
\text { Spain } \\
\text { Germany }\end{array}$ \\
\hline Brazil & $\begin{array}{l}\text { Portugal } \\
\text { USA } \\
\text { Argentina } \\
\text { New Zealand } \\
\text { Bolivia } \\
\text { Angola }\end{array}$ \\
\hline France & $\begin{array}{l}\text { UK } \\
\text { Switzerland } \\
\text { Ireland }\end{array}$ \\
\hline Pakistan & $\begin{array}{l}\text { UK } \\
\text { Qatar } \\
\text { United Arab Emirates } \\
\text { Australia } \\
\text { USA }\end{array}$ \\
\hline Lebanon & $\begin{array}{l}\text { Iraq } \\
\text { Qatar } \\
\text { Saudi Arabia } \\
\text { United Arab Emirates }\end{array}$ \\
\hline Colombia & $\begin{array}{l}\text { Chile } \\
\text { Panama } \\
\text { Spain } \\
\text { Barbados } \\
\text { USA }\end{array}$ \\
\hline Egypt & $\begin{array}{l}\text { Kuwait } \\
\text { Saudi Arabia } \\
\text { Sudan } \\
\text { Qatar } \\
\text { Yemen } \\
\text { Saudi Arabia }\end{array}$ \\
\hline Poland & $\begin{array}{l}\text { Ireland, Republic of } \\
\text { Antigua and Barbuda }\end{array}$ \\
\hline
\end{tabular}

Table 2 (continued)

\begin{tabular}{|c|c|}
\hline Direction & Origin Country \\
\hline \multirow{14}{*}{ Turkey } & UK \\
\hline & Austria \\
\hline & Cuba \\
\hline & Greece \\
\hline & Germany \\
\hline & Germany \\
\hline & USA \\
\hline & Cyprus \\
\hline & Nigeria \\
\hline & Saudi Arabia \\
\hline & Iraq \\
\hline & UK \\
\hline & Sweden \\
\hline & Canada \\
\hline \multirow[t]{16}{*}{ India } & Malaysia \\
\hline & Oman \\
\hline & Latvia \\
\hline & Kenya \\
\hline & Afghanistan \\
\hline & Nigeria \\
\hline & Iraq \\
\hline & USA \\
\hline & South Africa \\
\hline & Turkmenistan \\
\hline & Nigeria \\
\hline & Australia \\
\hline & UK \\
\hline & United Arab Emirates \\
\hline & Canada \\
\hline & Tanzania \\
\hline \multirow[t]{7}{*}{ Mexico } & USA \\
\hline & France \\
\hline & Canada \\
\hline & Venezuela \\
\hline & China \\
\hline & India \\
\hline & Australia \\
\hline \multirow[t]{6}{*}{ United States of America (USA) } & Poland \\
\hline & Mexico \\
\hline & Egypt \\
\hline & Ghana \\
\hline & Cameroon \\
\hline & Dominican Republic \\
\hline
\end{tabular}

analysis was performed using the SAS® software, University Edition (SAS Institute, Cary, NC, USA). Correlation analysis was used to investigate the association between a countries' gross domestic product (purchasing power parity) per capita (GDP) and the costs of treatment. GDP was expressed in the Geary-Khamis dollar or the international dollar (Int\$), a hypothetical unit of currency that has the same purchasing power parity that the US dollar had in the USA at a given point in time and provides a more valid measure to compare standards of living. The fluxes of patients were presented using the ArcGIS online tool (www.maps.arcgis.com). 


\section{Results}

Table 1 summarizes the number of bariatric procedures reported by the responders. Ninety-three responders performed 18,001 procedures in 2017. Sixty-four of those 93 responders operated on foreign patients - bariatric tourists - and performed a total of 3740 operations for this group of patients. The majority of the responders practice in India $(n=11,17 \%)$, Mexico $(n=10$, $16 \%)$, and Turkey $(n=6,9 \%)$. Mexico dominated the number of bariatric surgeries for tourist with 2557 procedures performed in 2017. The most frequent procedures provided for tourists were laparoscopic sleeve gastrectomy (LSG) provided by $89.1 \%$ of the respondents, laparoscopic Roux-en-Y gastric bypass (40.6\% of respondents), and one anastomosis gastric bypass (37.5\% of respondents). Fifty-two of our participants qualified foreign patients for surgery during personal consultation $(81.2 \%)$ and $13(20 \%)$ admitted using another physicians' referral with 32
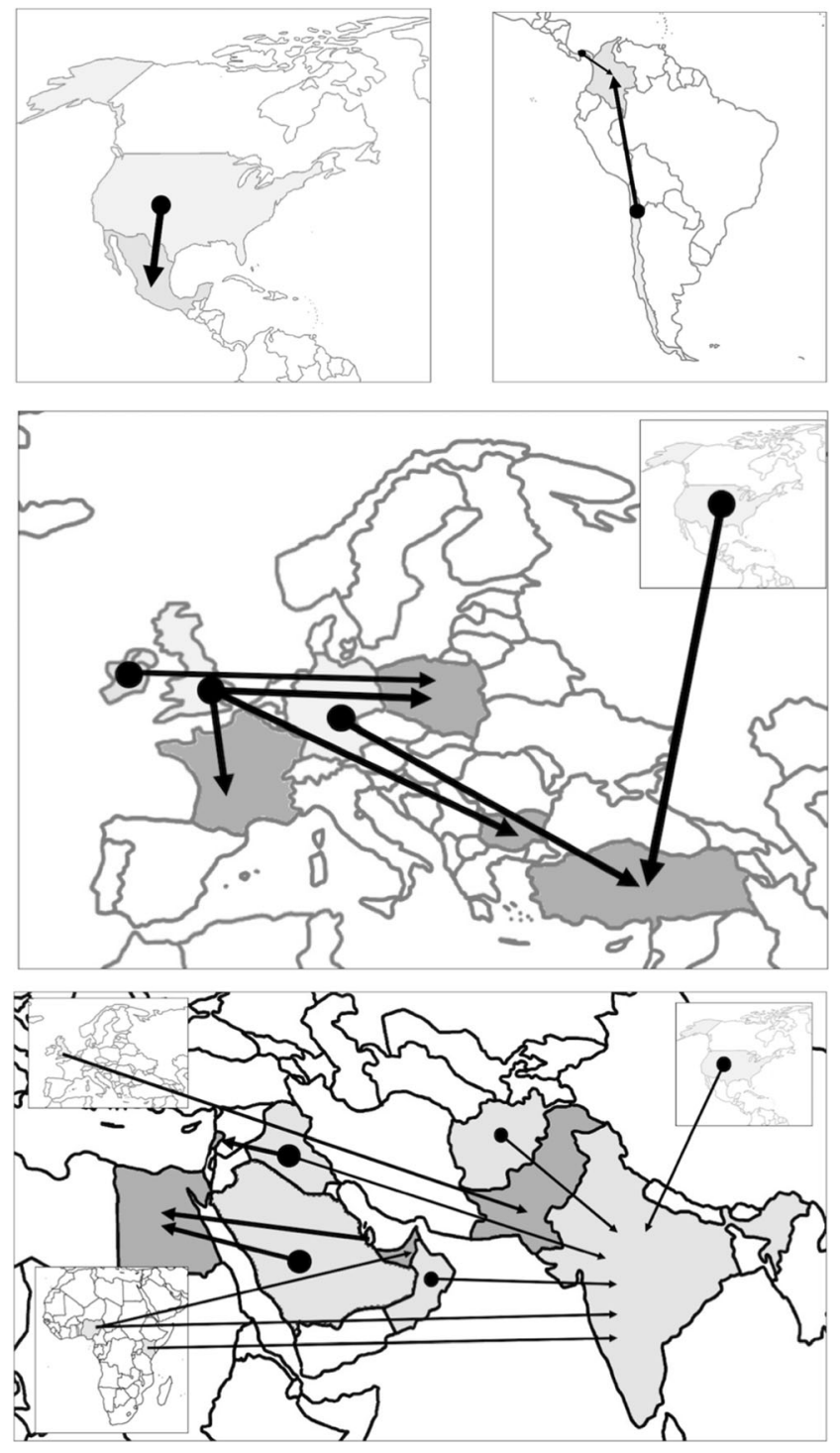

Fig. 1 Major fluxes of patients in selected regions
(50\%) used "video consultation and lab results evaluation." When asked the reasons for foreign patients choosing bariatric tourism, our respondents stated the high cost of private sector bariatric surgery in the patients' country of origin was the reason in $54.7 \%$, long waiting list in public sector in $42.2 \%$ of patients, the respondent's global recognition in $35.9 \%$, lack of insurance coverage $(37.5 \%)$, and lack of bariatric healthcare in the country of origin $(31.2 \%)$.

\section{Main Fluxes}

The countries of origin of patients seeking bariatric tourism from this survey are outlined in Table 2. The fluxes are presented on Fig. 1. Surgeons from India, who were the most common in our survey, did not specify one dominant country of origin, yet when we analyzed responses from the Middle East and Asia as a whole we discovered that the United Arab Emirates, Saudi Arabia, and USA provided most patients in this region.

When it comes to the Americas, most of our participants came from Mexico and US citizens were their main clients, followed by patients from Canada. In Europe, Turkish responders operated mainly on patients from Germany, Iraq, USA, and Canada. The most frequently mentioned European tourists came from the UK.

\section{Economy}

The mean estimated cost of surgery was 7760 USD $( \pm 4035$ USD), yet we received prices as low as 2300 USD for a laparoscopic sleeve gastrectomy in Egypt and 2500 USD in Turkey. A weak positive correlation was observed between GDP per capita and the estimated cost of the bariatric procedure $(r=0.474, p<0.001)$ (Fig. 2).

Relationship between GDP per capita and costs of treatment

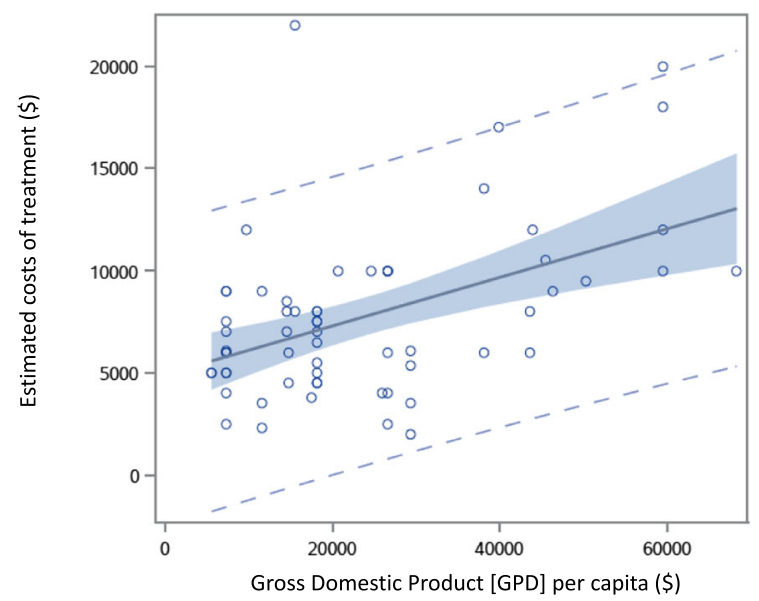

Fig. 2 Relationship between country's GDP per capita and cost of treatment 
Table 3 The results of the questionnaire

$\begin{array}{ll}\text { Item } & \text { Percentage }(\%) \text { or number }(n)\end{array}$

What type of procedure did you perform FOR THE TOURISTS? (surgeons can choose more than one)

$\begin{array}{ll}\text { LSG } & 89.1 \%\end{array}$

$\begin{array}{ll}\text { LRYGB } & 40.6 \%\end{array}$

OMGB $\quad 37.5 \%$

$\begin{array}{ll}\text { LAGB } & 7.8 \%\end{array}$

GP $\quad 4.7 \%$

DS $\quad 3.1 \%$

SADI $\quad 3.1 \%$

Other $\quad 9.4 \%$

How many TOURISTS with BMI under 35 did you treat last year?
Number $(n)$

While qualifying for surgery do you request /perform:

Upper GI endoscopy $\quad 82.8 \%$

$\begin{array}{ll}\text { Abdominal ultrasonography } & 71.9 \%\end{array}$

$\begin{array}{ll}\text { Psychological consult } & 78.1 \%\end{array}$

$\begin{array}{ll}\text { Dietary consult } & 84.4 \%\end{array}$

How do you qualify TOURISTS for surgery?

During a personal consultation $\quad 81.3 \%$

$\begin{array}{ll}\text { By other physician's referral } & 79.7 \%\end{array}$

With video consultation + lab results evaluation $\quad 50.0 \%$

Do you give TOURISTS post-op instructions in English / native language?

Yes

$98.4 \%$

Do you give TOURISTS dietary instructions in English / native language?

Yes $\quad 98.4 \%$

Do you give TOURISTS discharge documents (with detailed type of procedure / lab results etc.) in English / native language?

Yes $\quad 98.4 \%$

What type of follow-up do you provide for the TOURISTS?

$\begin{array}{ll}\text { Personal consultation } & 54.7 \%\end{array}$

$\begin{array}{ll}\text { Video consultation } & 57.8 \%\end{array}$

$\begin{array}{ll}\text { Phone consultation } & 70.3 \%\end{array}$

$\begin{array}{ll}\text { E-mail correspondence (with scans etc.) } & 78.1 \%\end{array}$

How long do you maintain personal follow-up for TOURISTS?

$\begin{array}{ll}\text { Till the removal of stitches } & 12.7 \%\end{array}$

Up to one month $\quad 4.8 \%$

Up to 3 months $\quad 4.8 \%$

$\begin{array}{ll}\text { Longer than } 3 \text { months } & 77.8 \%\end{array}$

Do you routinely recommend follow-up by a bariatric team in the country of origin?

Yes

$72.6 \%$

Did your bariatric tourist patients ever have experienced any complications related to surgery during follow-up?

$\begin{array}{ll}\text { Yes } & 22.2 \%\end{array}$

$\begin{array}{ll}\text { No } & 65.1 \%\end{array}$

I do not have data on that $\quad 12.7 \%$

Type of reported complications:

Gastric leak or anastomotic leak $\quad 7.8 \%$

Postoperative bleeding - INTRABDOMINAL $\quad 4.7 \%$

Postoperative bleeding - ENDOLUMINAL. $\quad 1.6 \%$

VENOUS thromboembolism (VTE) $\quad 7.8 \%$

$\begin{array}{ll}\text { Ileus } & 4.7 \%\end{array}$

$\begin{array}{ll}\text { Internal hernia } & 1.6 \%\end{array}$ 
Table 3 (continued)

\begin{tabular}{ll}
\hline Item & Percentage $(\%)$ or number $(n)$ \\
\hline Where most complications were treated. & \\
Country of origin & $50 \%$ \\
Country where the primary procedure was done & $50 \%$ \\
Did any of your bariatric tourist patients ever died due to surgical complications? & $0 \%$ \\
Yes & $96.8 \%$ \\
No & $3.2 \%$ \\
I do not have data on that & \\
\hline
\end{tabular}

\section{Follow-up}

When it comes to follow-up, each of our respondents provided his foreign patients with discharge documents, along with post-operative instructions in English or even the patients' native language. Forty-nine surgeons (77.8\%) maintained follow-up of over 3 months, yet 8 of them (12.7\%) maintained it only until stitches/clips were removed. Only 45 bariatric specialists $(72.6 \%)$ routinely recommended follow-up by a bariatric team in the country of origin (Table 3 ).

\section{Reported Complications}

Fourteen (22.2\%) surgeons reported experiencing complications regarding bariatric tourists. Venous thromboembolism $(n=5,7.8 \%)$ and gastric/anastomotic leak $(n=5,7.8 \%)$ were the most frequent followed by ileus $(n=3,4.7 \%)$ and internal bleeding ( $n=3,4.7 \%$ ) (Table 3$)$.

\section{Discussion}

Medical tourism is a complex global health issue, and there is a need for more information about its scale [2]. When discussed, it often arouses controversies, especially when the authors compare US prices to private hospitals in developing countries, such as India [3]. First, we are struck by the inequality. Then, we found out that the real number of tourists is unknown. Since a service is cheaper, some surgeons perceive the care is not of the same quality. In fact, some argue that the medical tourism approach to obesity "is inappropriate and raises clear ethical and moral issues" [4]. When we applied our results to the global number of bariatric procedures [5], we estimated that at least $1.9 \%$ of all worldwide obesity surgeries were performed for bariatric surgery tourists. The percentage may be higher, but as we were not able to reach every surgeon providing such services for foreign patients we cannot know for sure. Nevertheless, this survey from 64 surgeons who performed 3740 procedures for tourists may actually reflect the current status of global bariatric tourism. We were not surprised that developing countries dominate as providers, since high prices in the private sector in the patients' homeland is the most common reason for tourists seeking medical services abroad. Mean price for bariatric surgery in Turkey reaches 8000 USD, 7000 USD in Mexico, and 6000 USD in India. In the USA, these prices range from 18,000 to 22,000 USD. Long waiting lists were the second reason behind bariatric tourism, possibly in countries with more restrictive indications for surgery, such as the UK where the majority of patients' are treated in a public healthcare system $[6,7]$. The lack of bariatric healthcare in the country of origin was an issue according to $34 \%$ of our participants. When we compare this fact to obesity prevalence in developing countries [8, 9], we see that the global medical community is failing to provide adequate healthcare for patients in these countries. It may be especially important considering the United Nations' sustainable development goals and its effort to provide comparable, quality healthcare worldwide by 2030 [10]. Only one surgeon provided his services strictly for tourists, and three of our participants treated foreign patients in over $50 \%$ of their procedures performed which indicates that domestic private/public patients dominate their practice. Further longitudinal studies are necessary to evaluate these tendencies. While discussing the follow-up provided by our responders, we noted only $80 \%$ recommend bariatric check-ups in the country of origin, which is surprising, since we know that a more strict long-term follow-up provides better results [11]. In addition, venous thromboembolism (VTE) was the most commonly reported complication, which we attribute to air travel. We do not have data whether or not VTE episodes were related to pulmonary embolism.

\section{Limitations and Controversies}

This is a survey-based study and therefore has important limitations such as being prone to recall bias and cannot provide precise data regarding patients (e.g., exact number of patients from 
one country treated in another, their gender). Global databases would be required to provide more accurate data. We are also aware that for some of our respondents bariatric tourism is their main source of income; therefore, their answers may present bariatric tourism in a more favorable light. None of our responders reported any fatalities, which is unusual for over 3700 cases. It may question our responders' thoroughness of their follow-up. Further research regarding bariatric tourist coming back to their homeland will shed more light on the actual level of complications and mortality rate among bariatric tourists.

The second limitation of this survey is our low response rate from IBC members. However, this survey is currently the first attempt to describe and estimate the scale of bariatric tourism. The low response rate might be attributed to various myths and controversies that accompany medical tourismthe major one stating that it is a cheaper, therefore a worse service [4].

In our view, the major controversy of this study is the fluxes: the first, obvious one, where a large group of patients from countries with high GDP travel to the ones with substantially lower GDP to receive a medical procedure otherwise economically unavailable in their homeland. But there is a second, reverse, smaller flux of wealthy patients who traveled to high GDP countries. The United Arab Emirates welcomed patients from Nigeria, Bahrain, and Iraq. Belgian bariatric specialists treated patients from Ivory Coast and Congo, while the USA was the final destination for tourists from Egypt, Mexico, and Cameroon.

\section{Conclusions}

At least $2 \%$ of worldwide bariatric procedures are provided for medical tourists. Countries such as Mexico, Lebanon, and Romania dominate as providers for patients mainly from the USA, UK, and Germany. The lack of affordable bariatric healthcare and long waiting lists are some of the reasons for patients choosing bariatric tourism. Further research regarding domestic complications of homecoming bariatric tourists may provide answers to pending questions regarding this topic.

\section{Compliance with Ethical Standards}

Conflict of Interest The authors declare that they have no conflict of interest.
Ethical Statement All procedures performed in studies involving human participants were in accordance with the ethical standards of the institutional and/or national research committee and with the 1964 Helsinki declaration and its later amendments or comparable ethical standards.

Consent Statement Not applicable.

Open Access This article is distributed under the terms of the Creative Commons Attribution 4.0 International License (http:// creativecommons.org/licenses/by/4.0/), which permits unrestricted use, distribution, and reproduction in any medium, provided you give appropriate credit to the original author(s) and the source, provide a link to the Creative Commons license, and indicate if changes were made.

\section{References}

1. Khorgami Z, Shoar S, Andalib A, et al. Trends in utilization of bariatric surgery, 2010-2014: sleeve gastrectomy dominates. Surg Obes Relat Dis. 2017;13:774-8.

2. Lunt N, Smith RD, Mannion R, Green ST, Exworthy M, Hanefeld $\mathrm{J}$, et al. Systematic review: what do we know about medical tourism? NIHR J Libr. 2014.

3. Herrick DM. Medical tourism: global competition in health care. 2007;

4. Birch DW, Vu L, Karmali S, et al. Medical tourism in bariatric surgery. Am J Surg Elsevier. 2010;199:604-8.

5. Higa K, Facs M, Himpens J, Welbourn R, Fres M, Dixon J, et al. The IFSO Global Registry Third IFSO Global Registry Report 2017.

6. Fried M, Hainer V, Basdevant A, et al. Interdisciplinary European guidelines on surgery for severe obesity. Rozhl Chir. 2008;87:468 76.

7. Weight loss surgery - availability - NHS [Internet]. [cited 2018 Oct 9]. Available from: https://www.nhs.uk/conditions/weightloss-surgery/who-can-have-it/

8. Prentice AM. The emerging epidemic of obesity in developing countries. Int J EpidemiolOxford University Press. 2006;35:93-9.

9. Popkin BM, Adair LS, Ng SW. Global nutrition transition and the pandemic of obesity in developing countries. Nutr Rev Wiley/ Blackwell (10.1111); 2012;70:3-21.

10. Meara JG, Leather AJM, Hagander L, et al. Global surgery 2030: evidence and solutions for achieving health, welfare, and economic development. Lancet (London, England). Elsevier. 2015;386:569 624.

11. McGrice M, Don Paul K. Interventions to improve long-term weight loss in patients following bariatric surgery: challenges and solutions. Diabetes Metab Syndr ObesDove Press. 2015;8:263-74.

Publisher's Note Springer Nature remains neutral with regard to jurisdictional claims in published maps and institutional affiliations. 